УДК $342.9: 351.711(477)$

DOI https://doi.org/10.51989/NUL.2021.5.5

\title{
КОРУПЦІЙНІ РИЗИКИ В ПИТАННІ ЗАЛУЧЕННЯ МІЖНАРОДНОЇ ДОПОМОГИ У СФЕРІ БЕЗПЕКИ Й ОБОРОНИ УКРАЇНИ
}

\author{
Голоднова Тетяна Станіславівна, \\ кандидат юридичних наук, \\ співробітник Служби безпеки України
}

У статті проаналізовано чинне законодавство України та розглянуто юридичну літературу щодо поняття «міжнародна допомога у сфері безпеки й оборони України». Доведено, що основними напрямами співробітництва України із країнами-донорами є забезпечення та відновлення територіальної цілісності та захисту суверенітету держави, а також забезпечення міжнародної підтримки процесів розвитку та реформування Збройних сил України й інших військових формувань України.

0б'єктом наукового аналізу в межах досліджуваної роботи виступають суспільні відносини, які виникають у процесі виявлення корупційних ризиків у питанні залучення міжнародної допомоги у сфері безпеки й оборони України.

Предметом дослідження є адміністративно-правові засади корупційних ризиків у питанні залучення міжнародної допомоги у сфері безпеки й оборони України.

Методологічною основою дослідження проблемних питань у роботі є комплексна система загальнонаукових та спеціальних методів: порівняльно-правовий метод; методи системного аналізу та синтезу; метод наукового пізнання; метод прогнозування.

Інформаційну й емпіричну базу дослідження становлять узагальнення практичної діяльності із застосуванням законодавства щодо корупційних ризиків у питанні залучення міжнародної допомоги у сфері безпеки й оборони України.

Аргументовано особливості корупційних ризиків, пов'язаних із наданням міжнародної допомоги у сфері безпеки й оборони, досліджено практичні проблеми таких ризиків у даній сфері, які можуть призвести до нецільового використання майна, допомоги загалом. Проаналізовано погляди науковців щодо контролю міжнародної допомоги у сфері безпеки й оборони в Україні. На основі проведеного дослідження запропоновано шляхи вдосконалення щодо виявлення корупційних ризиків у питанні залучення міжнародної допомоги у сфері оборони.

Ключові слова: ризики, корупційні ризики у сфері безпеки і оборони, міжнародна допомога у сфері безпеки й оборони.

Holodnova Tatyana. Corruption risks in attracting international assistance in the field of security and defense of Ukraine

The article analyzes the current legislation of Ukraine and considers the legal literature on the concept of «international assistance in the field of security and defense of Ukraine». It has been proved that the main directions of Ukraine's cooperation with donor countries are to ensure and restore the territorial integrity and protect the sovereignty of the State, as well as to ensure international support for the development and reform of the Armed Forces of Ukraine and other military formations of Ukraine.

The object of scientific analysis within the framework of the research work is public relations that arise in the process of identifying corruption risks in the issue of attracting international assistance in the field of security and defense of Ukraine.

The subject of the study is the administrative and legal principles of corruption risks in the issue of attracting international assistance in the field of security and defense of Ukraine.

The methodological basis for the study of problematic issues in the work is a comprehensive system of general scientific and special methods: comparative and legal method; method of system analysis and synthesis; method of scientific cognition; forecasting method.

The information and empirical base of research of this work is a generalization of practical activities with the application of legislation on corruption risks in the issue of attracting international assistance in the field of security and defense of Ukraine. 
The peculiarities of corruption risks related to the provision of international assistance in the field of security and defense are argued and practical problems of such risks in this area are investigated, which can lead to inappropriate use of property, assistance in general.

Key words: risks, corruption risks in field of security and defense, international assistance in field of security and defense.

Постановка проблеми. Протягом 2014-2021 рр. Україна від північноамериканських та європейських партнерів отримала допомогу у сфері безпеки й оборони. До основних донорів можна віднести США, Великобританію, Канаду, які передали українській стороні нелетальне озброєння, також надавалась консультативна допомога щодо реформування Збройних сил України, проводилися навчання окремих підрозділів військових формувань України.

Однією 3 найактуальніших проблем в Україні була і залишається корупція, яка набула системного характеру в усіх сферах суспільства, в управлінні державними ресурсами та секторі оборони також.

На жаль, до найбільш істотних корупційних ризиків у секторі безпеки й оборони України можна віднести відсутність покарання за корупційні злочини в цій сфері, а також надмірну засекреченість, яка обмежує доступ до інформації та громадського контролю.

Варто зазначити, що вирішити проблеми корупції в питанні залучення міжнародної допомоги у сфері безпеки й оборони України можна за допомогою реалізації комплексу антикорупційних заходів, які повинні цілеспрямовано здійснюватися в усіх сферах суспільних відносин.

Необхідно розуміти, що антикорупційні заходи в питанні залучення міжнародної допомоги у сфері безпеки й оборони України повинні спрямовуватися не лише на знищення корупції як явища, а й на усунення першопричин даного явища, які можуть сприяти його виникненню.

У зв'язку із цим виникає необхідність дослідження корупційних ризиків у питанні залучення міжнародної допомоги у сфері безпеки й оборони України, необхідно провести короткий аналіз корупційних ризиків у зазначеній сфері, подальше закріплення превентивних антикорупційних заходів, які сприятимуть підвищенню рівня ефективності застосування отриманої допомоги й експлуатації обладнання професійно підготовленими кадрами, що потенційно може збільшити обсяг допомоги в майбутньому.

Отже, актуальність постановки та вирішення зазначеного питання зумовлюється неналежним рівнем підвищення прозорості та підзвітності в питаннях планування отримання допомоги, контролю за використанням такої допомоги на території України.

Стан дослідження. Загальнотеоретичними питаннями корупційної проблематики в секторі безпеки й оборони присвячена увага, але зазначимо, що проблема корупційних ризиків у цій сфері $\epsilon$ актуальною натепер. Окремі аспекти корупції у сфері безпеки й оборони вивчали як вітчизняні науковці (А. Баланда [1], К. Бугайчук [16], А. Волошенко [2], М. Голомша [3], О. Голота [4], Ю. Дмитрієв [5], В. Коваленко [7], Т. Ковальчук [7], Н. Ковальчук [8], О. Котляренко [9], $€$. Невмержицький [10]), так і зарубіжні вчені (Кос Драго [17], М. Пайман [11], С. Роуз-Аккерман [12]), інші науковці.

У зв'язку зі змінами, які відбуваються в антикорупційному законодавстві, та наділенням суб'єктів повнованнями управляти майном військових формувань в Україні, спеціальні комплексні дослідження щодо корупційних ризиків у питаннях залучення міжнародної допомоги у сфері безпеки й оборони не проводилися.

Метою статті $\boldsymbol{\epsilon}$ проведення аналізу наукових праць та нормативно-правових актів щодо визначення корупційних ризиків у питанні залучення міжнародної допомоги у сфері безпеки й оборони України. Дослідження зосереджено на виявленні корупційних ризиків у сфері залучення міжнародної допомоги, яка надається у вигляді матеріально-технічних засобів, надання відповідних рекомендацій щодо механізмів зниження корупційних ризиків у зазначеній сфері.

Виклад основного матеріалу. Міжнародна допомога у сфері безпеки й оборони для 3бройних сил України й інших військових формувань України залучається пере- 
важно у вигляді гуманітарної допомоги (далі - ГД) та міжнародної технічної допомоги (далі - МТД). Окрім цього, допомога може залучатися як благодійна допомога на основі двостороннього договору. Однак нормативно-правова база регулює гуманітарну допомогу та міжнародну технічну допомогу у сфері безпеки й оборони для Збройних сил України й інших військових формувань України.

Гуманітарна допомога - цільова адресна безоплатна допомога у грошовій або натуральній формі, у вигляді безповоротної фінансової допомоги або добровільних пожертвувань, або допомога у вигляді виконання робіт, послуг, що надається іноземними та вітчизняними донорами з гуманних мотивів отримувачам гуманітарної допомоги в Україні або за кордоном, які потребують ії у зв'язку із соціальною незахищеністю, матеріальною незабезпеченістю, важким фінансовим становищем, виникненням надзвичайного стану, зокрема внаслідок стихійного лиха, аварій, епідемій і епізоотій, екологічних, техногенних та інших катастроф, які створюють загрозу для життя і здоров'я населення, або тяжкої хвороби конкретних фізичних осіб, а також для підготовки до збройного захисту держави, її захисту в разі збройної агресії або збройного конфлікту [14, ст. 1]. Отже, гуманітарна допомога у сфері безпеки й оборони України може залучатися також у натуральній формі, у вигляді добровільних пожертвувань, виконання робіт, надання послуг, залучення грошової форми допомоги тощо.

Міжнародна технічна допомога - це фінансові й інші ресурси та послуги, що відповідно до міжнародних договорів України надаються донорами на безоплатній та безповоротній основі з метою підтримки України [15, ст. 1]. Допомога, яка передається як МТД, може залучатися у вигляді будь-якого майна, необхідного для забезпечення виконання завдань, проєктів, програм, що ввозиться або набувається в Україні, робіт, послуг, прав інтелектуальної власності, інших ресурсів, не заборонених законодавством, зокрема і стипендій [15]. Залучення МТД здійснюється з метою додаткового забезпечення Збройних сил України матеріально-технічними засобами.
Під термінами «допомога у сфері безпеки» у США, «військове залучення» у Сполученому Королівстві, «військова допомога» у Канаді розуміється як допомога країнам у протидії спільним викликам, для покращення співпраці, взаємодії й обміну ресурсами, а також допомога в нарощуванні потенціалу військовими формуваннями країн - отримувачів допомоги [20].

Що ж стосується отримання Україною міжнародної допомоги у сфері безпеки Збройних сил України, то необхідно дотримуватися алгоритму вимог щодо ії отримання. Алгоритм такий:

Організація залучення МТД: а) формування відповідних запитів (визначення потреб відповідно до номенклатури каталогу предметів, зазначення тактико-технічної характеристики тощо; б) реєстрація допомоги; в) увезення, отримання і розподіл матеріально-технічної допомоги; г) ведення обліку МТД.

Міжнародна допомога може залучатися лише тими органами, які уповноважені ії використовувати та зможуть запобігти незаконному привласненню [18]. Однак, на нашу думку, законодавцем у наказі Міністерства оборони України «Про затвердження Інструкції про організацію залучення, використання, обліку та моніторингу міжнародної технічної допомоги в Міністерстві оборони України та Збройних Силах України» від 1 лютого 2018 р. № 37 не було враховано окремого розділу щодо контролю за використанням матеріальнотехнічної міжнародної допомоги у сфері оборони, розділу «Звітування щодо використання допомоги», також немає інформації щодо списання майна, яке надано як міжнародна допомога у сфері оборони.

Варто зазначити, що останнім часом облік та контроль щодо формування, отримання, розподілу та використання міжнародної допомоги у сфері безпеки й оборони в Україні помітно покращилися, але корупційні ризики наявні в різних процесах отримання такої допомоги.

Під час формування вимог щодо оформлення міжнародної допомоги у сфері безпеки й оборони наявні проблеми правового регулювання зазначеного процесу, а також $\epsilon$ потенційне зловживання та неефективність використання військового 
майна, що суттєво скорочує ефективність отримання такої допомоги, надалі з'являються ризики незаконного привласнення військового майна.

На думку Я. Степановської, «процеси контролю й обліку військового майна значно покращилися порівняно із 2014 р., коли вони були досить хаотичними в умовах відбиття добровольчими батальйонами та Збройними силами України російської агресії. Упродовж 2014-2015 рр. добровольчі батальйони були інтегровані до формальних військових структур, що уніфікувало та посилило формальні процедури і процедури обліку військового майна» [19].

Корупційні ризики в питанні залучення міжнародної допомоги у сфері безпеки й оборони України створюють загрозу системі управління, розподілу, використання військового майна за цільовим призначенням. Тому одним із пріоритетних напрямів у сфері запобігання корупції в питанні залучення міжнародної допомоги у сфері оборони $є$ своєчасне визначення корупційних ризиків, які виникають у процесі розподілу, використання, списання військового майна, а також пряме усунення умов та причин утворення таких ризиків.

Під час виконання завдань, функцій, досягнення цілей і планів щодо отримання міжнародної допомоги у сфері безпеки й оборони України військові формування стикаються з певними обставинами, які можуть впливати на здатність до отримання такої допомоги.

Корупційні ризики в питанні залучення міжнародної допомоги у сфері безпеки й оборони можуть бути спричинені внутрішніми і зовнішніми чинниками.

До основних корупційних ризиків у зазначеному напрямі, які мають визначальний вплив на досягнення цілей і ефективного управління матеріальними ресурсами можна віднести такі ризики:

- незаконне списання матеріальних цінностей, отриманих від країн-донорів;

- недостовірне ведення обліку отриманого в допомогу майна;

- перевитрати моторесурсу понад встановлені норми;

- неякісне та формальне проведення інвентаризації;
- несвоєчасне проведення звірок;

- несвоєчасне поповнення озброєння до визначених норм тощо.

На нашу думку, зазначені корупційні ризики мають негативний влив на здатність організації користування міжнародною допомогою у сфері безпеки й оборони, зокрема й щодо виконання визначених актами законодавства функцій та завдань для досягнення мети у сфері безпеки.

Пропонуємо корупційні ризики в питанні залучення міжнародної допомоги у сфері безпеки й оборони поділити так:

- зовнішні корупційні ризики, імовірність виникнення яких не пов'язана з організацією та виконанням завдань і функцій в отриманні такої допомоги;

- внутрішні корупційні ризики, виникнення яких напряму пов'язано з організацією й отриманням, а потім використанням міжнародної допомоги у сфері безпеки й оборони.

В аспекті питання, що розглядається, зауважимо, що корупційні ризики в напрямі міжнародної допомоги у сфері безпеки й оборони можна розділити так:

Нормативно-правові - відсутня або нечітка реґламентація, наявність суперечностей у законодавчій базі щодо виконання завдань і функцій в організації й отриманні такої міжнародної допомоги.

Фінансово-господарські корупційні ризики в разі неналежного матеріального та ресурсного обліку отриманого в допомогу майна.

Репутаційні - події або ж дії, які можуть впливати негативно на репутацію військового формування, яке організовує отримання міжнародної допомоги у сфері безпеки й оборони.

Програмно-технічні корупційні ризики цілковита або часткова відсутність необхідних технічних засобів, програмного забезпечення або змін до нього.

Кадрові корупційні ризики - неналежне дотримання посадових інструкцій або ж неналежна професійна підготовка осіб, які виконують завдання щодо організації в отриманні міжнародної допомоги у сфері безпеки й оборони.

Корупційні - безконтрольність із боку керівництва військового формування, яке отримує таку допомогу; наявність дискреційних повноважень чи інші чинники, 
які сприяють або ж не можуть запобігати виникненню корупції.

Як свідчить світовий досвід, сприятливі умови для корупційної діяльності часто виникають саме в оборонному секторі, де панують секретність та безкарність, що унеможливлює здійснення суворого нагляду та контролю. У багатьох суспільствах різних країн панує думка, що збройні сили $є$ менш корумпованими, ніж політичні партії, законодавча влада, комерційні підприємства або засоби масової інформації. Однак показники корумпованості збройних сил є досить різними для різних країн та регіонів світу [13].

Незважаючи на загальне вдосконалення системи, донори все ще занепокоєні нездатністю України здійснювати ефективний контроль наданої допомоги, хоча українська сторона і дала чітко зрозуміти свій намір значно поліпшити якість цих процесів. На думку держав-донорів, їхня власна обізнаність щодо стану наданої Україні допомоги значно обмежена через ситуації в зонах тимчасово окупованих територій в Україні, недоліки процедури обліку військового майна. Ведення паперового обліку та відсутність автоматизації цих процесів значно ускладнюють контроль у режимі реального часу. Процес запровадження програми інвентаризації й обліку був призупинений на деякий час, що все ще залишає контроль за військовим майном на регіональному рівні та на рівні підрозділів досить складним. Отже, хоча й існують процедури фінансових санкцій за втрачене майно, проводяться службові розслідування, у донорів немає впевненості в дотриманні цих процедур на практиці, а також у здатності відповідних органів ефективно контролювати надану допомогу [21]. Інакше кажучи, державам-донорам досить складно проводити контроль у країнах-отримувачах за використанням міжнародної допомоги у сфері оборони.

Однак напрям усунення корупційних ризиків повинен передбачати постійний моніторинг усунення порушень та виконання рекомендацій керівника установи, яка отримує таку міжнародну допомогу. А зазначений моніторинг повинен здій- снюватися до повного усунення виявлених корупційних порушень та виконання аудиторських рекомендацій.

Висновки. Отже, корупційні ризики в питанні залучення міжнародної допомоги у сфері безпеки й оборони пропонуємо виділити за такими видами: нормативноправові, кадрові, програмно-технічні, репутаційні, фінансово-господарські, корупційні ризики.

Однак, на нашу думку, Україна не може отримати високотехнологічної допомоги від держав-донорів, оскільки ці держави непокоїть нецільове використання такої допомоги нашою державою. Невпевненість держав-донорів зумовлена тим, що Україна неналежним чином вберігає надану міжнародну допомогу від усіх корупційних ризиків, а як результат - наша держава не завжди отримує техніку й озброєння тієї якості, які 6 могли забезпечити потреби сил оборони України.

Нині в Україні $\epsilon$ досить розгалужена система контролю у сфері управління майном, отриманим за міжнародною допомогою. Автором пропонується військовим формування України підтримувати донорів шляхом запровадження програмного забезпечення контролю, проведення повної інвентаризації й обліку військового майна, яке отримано як допомога.

А також підтримка належного вдосконалення контролю за розподілом допомоги у сфері безпеки й оборони допоможе організувати довгострокове планування розподілу таких ресурсів, знизить прояв корупційних ризиків. Отже, надасть упевненості країнам-донорам в ухваленні рішень щодо організації допомоги. Зазначимо, що військові формування України повинні врахувати в майбутньому систему захисту технологій щодо використання отриманої міжнародної допомоги в заявлених цілях і напрямах з урахуванням корупційних ризиків із метою зниження ризиків нецільового використання отриманих ресурсів. А також мають організувати звітність із боку України з метою продовження організації й отримання міжнародної допомоги у сфері безпеки й оборони, що покращить контроль. 


\section{ЛITEPATУРА:}

1. Баланда А. Соціальні детермінанти національної безпеки України: теорія, методологія, практик а: автореф. дис. ... докт. екон. наук: 08.00.07. Київ, 2008. 40 с.

2. Волошенко А. Корупційні ризики в оборонній сфері: природа, чинники та шляхи мінімізації. Актуальні проблеми економіки. 2015. № 10 (172). С. 95-105.

3. Голота О. Ризики втрат державних коштів під час здійснення державних закупівель у Збройних Силах України та шляхи їх зниження. Актуальні проблеми національної економіки в інтересах оборони і безпеки держави та шляхи їх вирішення : збірник матеріалів доповідей учасників Науково-практичної конференції. Київ : НУОУ, 2015. С. 10-21.

4. Голомша М. Корупційні ризики оборонного сектору України. Посилення доброчесності та протидія корупції в оборонному секторі України : збірник матеріалів доповідей учасників Науково-практичної конференції. Київ : Національний інститут стратегічних досліджень, 2011. С. 20-22.

5. Дмитрієв Ю. Корупційні ризики у діяльності осіб, уповноважених на виконання функцій держави. Право знати все про податки і збори. 10.04.2015. № 14 (14). URL: http://www. visnuk.com.ua/ua/pubs/id/ 8207 (дата звернення: 25.08.2021).

6. Коваленко В. Фінансові ризики та шляхи їх мінімізації. Київ : Знання, 2011. С. 319.

7. Ковальчук Т. Економічна безпека і політика: із досвіду професійного аналітика. Київ : Т-во «Знання»; КОО, 2004. 638 с.

8. Ковальчук Т., Ковальчук Н. Макроекономічні ризики. Київ : Знання, 2012. С. 301.

9. Котляренко О. Сучасний стан протидії корупції у сфері використання коштів оборонного бюджету та військового майна. Юридична наука. 2013. № 7. С. 54-62.

10. Невмержицький $€$. Корупція як соціально-політичний феномен : автореф. дис. ... докт. політ. наук: 23.00.02. Київ, 2009. 34 с.

11. Пайман М. Транспаренсі Інтернешнел «Будування цілісності, виховання доброчесності та боротьба з корупцією у сфері оборони й безпеки: 20 практичних реформ» / Transparency International UK. Defence and Security Programme. URL: www. defenceagainstcorruption.org (дата звернення: 25.08.2021).

12. Роуз-Аккерман С. Коррупция и государство: причины, следствия, реформы. Москва, 2003. 356 c.

13. Виховання доброчесності та боротьба з корупцією в оборонному секторі: збірник прикладів (компендіум) позитивного досвіду. Женевський Центр демократичного контролю над збройними силами. Женева, 2010. 383 с.

14. Про гуманітарну допомогу : Закон України від 22 жовтня 1999 р. № 1192-XIV. Відомості Верховної Ради України. 1999. № 51. Ст. 451.

15. Про створення єдиної системи залучення, використання та моніторингу міжнародної технічної допомоги : постанова Кабінету Міністрів України від 15 лютого 2002 р. № 153. Офіційний вісник України. 2002. № 8. С. 101.

16. Бугайчук К. Корупційні ризики: поняття, класифікація, методологія оцінки, заходи усунення. URL: http: www.univd.edu.ua/general/ publishing/konf/ 31_03_2017/pdf/15.pdf (дата звернення: 26.08.2021).

17. Кос Дрого. Управління корупційними ризиками в державній службі України (Процедури оцінки корупційних ризиків в діяльності посадових осіб) : технічний посібник. URL: http: vkksu.gov.ua/userfiles/technical_book.pdf (дата звернення: 26.08.2021).

18. Про затвердження Інструкції про організацію залучення, використання, обліку та моніторингу міжнародної технічної допомоги в Міністерстві оборони України та Збройних Силах України : наказ Міністерства оборони України від 1 лютого 2018 р. № 37.

19. Степановська Я. Авангард нації. Куди зникли добровольчі батальйони. Ліга. Новини. 10 лютого 2017. URL: http/ news.liga.net/ua/artikles/politics/avangard nats kudi znikli dobrovolch batalyoni.htm (дата звернення: 05.09.2021).

20. Transparency International - Defence and Security. Security assistance, corruption and fragile environments. Exploring the case of Mali. 2001-2012. London, August 2015. URL: http:// ti-defence.org/wp content/uploads /2016/03/150818-150817-Security-assistance-corruption- 
and-fragile-environments-Exploring-the-case-of-Mali-2001-2012.pdf

(дата

звернення: 10.09.2021).

21. Shuster Simon. Corruption still plagues Ukraine as West pumps in Aid. Time Magazine. 1 квітня 2014. URL: http://time.com/45253/ukraine-corruption-tymoshenko-kiev/ (дата звернення: 01.05.2017) ; Pugliese David. No safeguards stopping Canadian equipment from falling into wrong hands in Ukraine, opposition MPs say. National Post. 20 вересня 2014. URL: http://news.nationalpost.com/news/canada/no-safeguards-stopping-canadian-equipmentfrom-falling-into-wrong-hands-in-ukraine-opposition-mps-say (дата звернення: 06.09.2021). 